\title{
Epidemiological status of felid herpesvirus type-1 and feline calicivirus infections in Brazil
}

\author{
Situação epidemiológica das infecções pelo herpesvírus felino tipo 1 e calicivírus no Brasil
}

\author{
Andréia Henzel ${ }^{\mathrm{I}}$ Luciane Teresinha Lovato ${ }^{\text {II, III }}$ Rudi Weiblen ${ }^{\text {III }}$
}

\section{- REVIEW -}

\begin{abstract}
Feline calicivirus (FCV) and felid herpesvirus type1 (FeHV-1) are the main infectious agents of domestic and wild felines worldwide. The FCV and FeHV-1 viruses were isolated in Brazil in 1988 and 2012, respectively. Serology surveys were performed among domestic feline in the State of Rio Grande do Sul and among wild felines in central Brazilian States. Felines with acute or chronic infections may become carriers for both viruses and, viral transmission occurs mainly by ocular and nasal secretions. In addition, FCV may be transmitted by oropharyngeal secretion and fomites. The clinical signs commonly observed in cats are fever, sneezing, coughing and nasal and ocular discharge; however, oral lesions are restricted to FCV infection. A systemic syndrome showing hemorrhagic lesions, alopecia, facial edema and jaundice has been associated with FCV. Attenuated as well as inactivated vaccines against $F C V$ and FeHV-1 were developed in the middle 1970s, and they are effective at reducing the presentation/development of the diseases, but they are not capable of eliminating the persistence of FCV and FeHV-1. This article presents a brief review of the main aspects of the FCV and FeHV1 infections, with an emphasis in the current situation on the domestic feline population from Brazil.
\end{abstract}

Key words: $F C V$, FeHV-1, respiratory and oral disease, vaccination.

\section{RESUMO}

Calicivírus felino (feline calicivirus - FCV) $e$ herpesvirus felino tipo - 1 (felid herpesvirus type 1 - FeHV-1) são os principais agentes envolvidos descritos mundialmente infectando felinos domésticos e selvagens. No Brasil, o FCV e o FeHV-1 foram isolados e caracterizados em 1988 e 2012, respectivamente. Estudos sorológicos em felinos domésticos foram realizados no estado do Rio
Grande do Sul e em felinos selvagens em alguns estados da região central do país. Felinos com infecção aguda elou infecção crônica podem tornar-se portadores, para ambos os virus, e a transmissão ocorre principalmente por secreções oculares, nasais. Além disso, o FCV pode também ser transmitido por secreções orofaringeanas e fômites. Os sinais clínicos comumente observados em felinos afetados são: febre, espirros, tosse, descarga nasal e ocular; lesões orais se restringem à infecção pelo FCV; além disso, foi descrita uma síndrome sistemica que apresenta um quadro hemorrágico, alopecia, edema de face e icterícia. Vacinas vivas e inativadas que amenizam o quadro clínico, mas não previnem infecções persistentes pelos virus, foram desenvolvidas nos anos 70. Este artigo apresenta uma breve revisão dos principais aspectos da infecção pelo $F C V$ e FeHV-1, com ênfase na atual situação na população de felinos domésticos do Brasil.

Palavras-chave: $F C V$, FeHV-1, doenças respiratórias e orais, vacinação.

\section{INTRODUCTION}

Respiratory infections in cats are frequent and of great importance in feline internal medicine. Feline calicivirus (FCV) and feline herpesvirus type1 (FeHV-1) are the main agents of upper respiratory tract disease (URTD) in cats (RADFORD et al., 2009; THIRY et al., 2009). Chlamydophila felis, Bordetella bronchiseptica and Mycoplasma felis are the other agents involved in this syndrome; however, they are secondary to FCV and FeHV-1 infection. These two viruses account for approximately 80 to

'Instituto de Ciências da Saúde (ICS), Laboratório de Microbiologia Molecular (LMM), Universidade Feevale, RS 239, 2755, sala 203, Bairro Vila Nova, 93352-000, Novo Hamburgo, RS, Brasil. E-mail: henzelvet@gmail.com. Corresponding author.

"Departamento de Microbiologia e Parasitologia, Centro de Ciências da Saúde, Universidade Federal de Santa Maria (UFSM), Santa Maria, RS, Brasil.

IIISetor de Virologia, Departamento de Medicina Veterinária Preventiva, Centro de Ciências Rurais, UFSM, Santa Maria, RS, Brasil. 
$90 \%$ of the cases of URTD, although there is a greater involvement of FCV than FeHV-1 (GASKELL \& KNOWLES, 1989). FCV also causes oral lesions, including ulcers, stomatitis and gingivostomatitis, and may also present as a highly fatal systemic disease (RADFORD et al., 2007). FeHV-1 can cause ocular lesions that may progress to glaucoma and corneal ulcers, and therefore blindness (GASKEL et al., 2007). Vaccination against FCV and FeHV-1 to be adopted in the 1970s. However, the isolation rates have not decreased since then furthermore; URTD remains responsible for high levels of morbidity and mortality in young cats (GASKELL \& KNOWLES, 1989). The viruses are distributed worldwide and have been isolated in Brazil in the State of Rio Grande do Sul [RS] (WEIBLEN et al., 1988; HENZEL et al., 2012b). Serological studies on domestic and wild cats have been performed in RS and in the West-Central region of Brazil (RUTHNER-BATISTA et al., 2005; JOHANN et al., 2009; HENZEL et al., 2013). The molecular characterization of FCV isolates has also been reported (HENZEL et al., 2012a). However, the current distribution and prevalence of these viruses is largely unknown in Brazil. Therefore, the present review aims to gather data on the clinical, virological and epidemiological aspects of both viruses in $\mathrm{RS}$ and in several other Brazilian states with an emphasis on the importance of the presence of FCV and FeHV1 in the non-immune population of cats.

\section{Etiology}

Feline herpesvirus type-1 (FeHV-1)

FeHV-1 is the infectious agent responsible for feline viral rhinotracheitis [FVR] (GASKELL et al., 2007). The initial isolation of FeHV-1 was described in 1957 in North America, and strain "C-27" was referred to as the virus prototype (CRANDELL \& MAURER, 1958).

FeHV-1 belongs to the Varicellovirus genus, which is in the Alphaherpesvirinae subfamily of the Herpesviridae family. FeHV-1 consists of double-stranded DNA of 134 kilobases $(\mathrm{Kb})$ with icosahedral capsids surrounded by a lipid envelope, presence of tegument between envelope and the capsid, and the diameter of virions range from 120 to 300nm (POVEY, 1979; GASKELL et al., 2007). The genome encodes five envelope glycoproteins that are important in the induction of humoral and cellular immunity (MAEDA et al., 1998). Some FeHV-1 isolates may differ in virulence, although all of them belong to one serotype (GASKELL et al., 2007).
Epidemiology

FeHV-1 is distributed worldwide and endemic in most populations (GASKELL et al., 2007). The information available in Brazil consists of serological studies in wild and domestic cats (RUTHNER-BATISTA et al., 2005; FILONI et al., 2006; JOHANN et al., 2009; HENZEL et al., 2013), and isolation of FeHV-1 in RS (HENZEL et al., 2012b).

Members of the Felidae family are the susceptible hosts, and there are no age, sex or breed predispositions to infection; however, the infection is more severe in cats of up to six months of age (POVEY 1979; GASKELL et al., 2007). The prevalence varies according to the population density; it may be lower than $1 \%$ in small groups and between 10 to $20 \%$ in large populations (GASKELL et al., 2007). Morbidity may reach $100 \%$ in young cats and in large populations, including those found in catteries, fairs and exhibitions, and mortality is high among newborns, young and debilitated cats. Recovery may occur in seven to 10 days. However, mortality may reach up to $50 \%$, associated to generalized infection among predisposed cats (GASKELL et al., 2007).

FeHV-1 persists in the population mainly by contact between cats with acute infection and susceptible cats. Latent infection, which is the persistence of the virus in clinically convalescent or vaccinated cats, is another important reason for the perpetuation of the virus (GASKELL \& KNOWLES, 1989). Approximately $90 \%$ of cats are seropositive all over the world. Furthermore, 80 to $100 \%$ of seropositive cats remain carriers for life, and approximately $45 \%$ may shed the virus intermittently (GASKELL \& POVEY, 1979). Antibodies against FeHV-1 were detected in $50-75 \%$ of the cat population in Great Britain and in 50 to $70 \%$ of the adult domestic cats in Germany (GASKELL et al., 2007). In Brazil, 38.1\% of 97 samples showed antibodies against FeHV-1 in a serological survey conducted in Pelotas, RS (JOHANN et al., 2009). The prevalence of antibodies against FeHV-1 was $30.6 \%$ in another study conducted with 630 serum samples provided by veterinary hospitals of the Federal University of Santa Maria (UFSM), University of Passo Fundo (UPF) and Federal University of Rio Grande do Sul (UFRGS) and from clinics in other cities of RS (HENZEL et al., 2013). Furthermore, FeHV-1 was isolated from single infections or co-infections with FCV in 26 of 302 samples from the cat population of RS. Between the 26 isolates, 14 were derived from cats with respiratory signs and 12 from asymptomatic felines (HENZEL et al., 2012b). 
Serological studies suggest that FeHV1 are also present in wild feline kept in captivity in Europe (DANIELS et. al., 1999) and Brazil (RUTHNER-BATISTA et al., 2005; FILONI et al., 2006). Antibodies were detected in studies conducted in Brazil in the serum from oncilla (Leopardus tigrinus), margay (Leopardus wiedii), ocelot (Leopardus pardalis), eyra cat (Herpailurus yaguarondi) jaguarundi (Herpailurus yaguarondi), cougar (Puma concolor) and jaguar (Panthera onca) (RUTHNER-BATISTA et al., 2005). In another study, $21.6 \%$ of the serum samples from cougars (Puma concolor) and leopards (Panthera pardus) were positive for FeHV-1 (FILONI et al., 2006).

Pathogeny and clinical signs

FeHV-1 infection occurs through nasal, conjunctival and oral routes. The infection is characterized by lytic replication in the epithelial cells of the mucous membranes of the nasal septum, turbinates, nasopharynx and tonsils; in addition, the conjunctiva, mandibular lymph node and upper trachea may also be involved. Viremia and/or generalized infection are not frequent, and the incubation period ranges from two to six days (GASKELL et al., 2007).

FeHV-1 establishes latency in neural tissues (GASKELL et al., 2007) and ascends the sensory nerves via axons after primary replication, with latency established in the trigeminal ganglion [TG] (MAGGS, 2005). Viral DNA was detected in the TG and non-neural tissues of cats during latency reactivation. FeHV-1 returns via axons and replicates in the primary site of infection, which is usually the turbinates (NASISSE et al., 1992; MAGGS, 2005). Latently infected cats may transmit FeHV1 to their progeny because parturition and lactation are stressors that may induce reactivation and viral shedding (GASKELL et al., 2007).

The clinical signs observed in both natural and experimental conditions are sneezing, loss of appetite, pyrexia, depression, nasal and ocular discharge (which may be serous and/or mucopurulent depending on the severity and secondary bacterial contamination), conjunctivitis (with hyperemia and/ or bruising) and, severe cases, dyspnea and cough (GASKELL et al., 2007). Conjunctivitis may be associated with corneal ulcers and may develop into stromal keratitis and blindness (THIRY et al., 2009). Fetal infection is reported, although abortion is rare. Abortion occurs in cats experimentally infected with FeHV-1 because of the systemic effects of the infection and not directly by the replication/pathogenesis of the virus itself (GASKELL et al., 2007).
Immunity

The immune response against FeHV1 is related to the recognition of viral envelope glycoproteins by the feline immune system. The induction of neutralizing antibodies occurs after infection, primarily against glycoprotein $\mathrm{gD}$ (MAEDA et al., 1998). However, the titers of antibodies induced by natural infection are often low and slowly increase, and may be absent until 40 days post-infection (THIRY et al., 2009). Furthermore, natural infection or vaccination fail to induce lasting immunity, and the induced response protects against the disease, although not re-infection (GASKELL \& POVEY, 1979). Other mechanisms of immunity, including the complement-mediated response, have been reported (THIRY et al., 2009). Moreover, since cellular immunity is essential for the defense against viral infections, antibodies against the glycoproteins are important for the neutralization of viral particles; nevertheless, the absence of detectable antibodies in the serum of vaccinated cats does not necessarily indicate that these animals remain susceptible to infection (GASKELL et al., 2007).

\section{Feline calicivirus (FCV)}

FCV virions are non-enveloped, with icosahedral capsids with 27 to $40 \mathrm{~nm}$ in diameter and a single-stranded and positive polarity RNA as genome; and it belongs to the Vesivirus genus of the Caliciviridae family (RADFORD et al., 2007). The genome has approximately $7.7 \mathrm{~Kb}$ and is organized in three open reading frames (ORFs). ORF 1 encodes non-structural proteins, ORF 2 encodes the main and largest capsid protein (viral protein - VP1) and ORF 3 encodes the smallest structural protein [VP2]. ORF 2 is divided into six regions (A to F) based on genetic variability. The regions $\mathrm{B}, \mathrm{D}$ and $\mathrm{F}$ are conserved, whereas $\mathrm{C}$ and $\mathrm{E}$ are variable. Region $\mathrm{E}$ is subdivided into hypervariable regions (HVR_E; RADFORD et al., 2007, 2009). The genes encoding immunodominant epitopes are present in E region, inducing neutralizing antibodies in the host. These genes play a key role in immune evasion during persistent infection (RADFORD et al., 2007).

FCV undergoes genetic mutations during replication and responds quickly to selection pressures from the host and environment (RADFORD et al., 2007). This genetic diversity compromises the effectiveness of vaccines. It complicates the induction of cross-protective vaccine immunity and infection control and contributes to persistent infection (RADFORD et al., 2009). The emergence of highly virulent FCV isolates (virulent systemic disease 
associated with feline calicivirus - FCV-VSD) is another key consequence of this genetic diversity (PEDERSEN et al., 2000). However, all FCV isolates belong to the same serotype, despite this diversity (RADFORD et al., 2007).

\section{Epidemiology}

The virus is widely distributed in the cat population (RADFORD et al., 2007), with the first isolate reported in New Zealand in 1957 (FASTIER, 1957) and in Brazil in 1988 (WEIBLEN et al., 1988).

Members of the Felidae family are the only hosts susceptible to FCV infection (RADFORD et al., 2007). In the United Kingdom, serological survey in wild cats showed that FCV were present in $50 \%$ of the tested sera (DANIELS et al., 1999). In Brazil, the serology showed the presence of antibodies against FCV in $21.6 \%$ of 21 serum samples analyzed from 1998 to 2004 (FILONI et al., 2006) collected in: cougars, leopards and jaguars. Antibodies against FCV were also detected in $56.7 \%$ of the 97 serum samples from domestic cats tested in Pelotas/ RS (JOHANN et al., 2009). Our research group detected antibodies against FCV in $39.2 \%$ of the 630 serum samples derived from cities neighboring the UPF, UFSM and UFRGS (HENZEL et al., 2013). Furthermore, FCV isolation and characterization in FeHV-1 single or mixed infections was reported in 34 of 55 positive cats in the virus isolation conducted on 302 swab samples, and such infections were more frequent in animals without clinical signs (HENZEL et al., 2012b). However, FCV has been isolated from 18 cats without any clinical manifestation at the time of collection and 4 cats with FeHV-1 co-infection confirmed by PCR (HENZEL et al., 2012b).

FCV transmission occurs through direct and indirect contact between cats. Secretions containing the virus may infect cages as well as the cleaning and food utensils in catteries, and they may be spread by human caretakers. In addition, the secretions may persist and remain infectious for up to a month on dry surfaces at room temperature and for longer periods at lower temperatures (RADFORD et al., 2007, 2009). Experimental intravenous infections and transmission through the cat flea Ctenocephalides felis have also been reported (MENCKE et al., 2009; RADFORD et al., 2009), although there is no evidence of the existence of reservoirs or alternative hosts for FCV infection and transmission (RADFORD et al., 2009). Moreover, a virus related to FCV was isolated in dogs; however the transmission between cats and dogs is uncertain (RADFORD et al., 2007). The prevalence of FCV is directly related to the number of cats present in a cattery and is higher in large groups, such as in colonies and shelters, where it may reach between 25 and $40 \%$. In addition, the prevalence of FCV may range from 50 to $90 \%$ in large groups; however small groups the prevalence is usually $10 \%$ (RADFORD et al., 2001).

FCV-VSD isolates cause up to $67 \%$ mortality in clinically healthy adult cats, and the epidemiology of the FCV-VSD syndrome is still poorly understood (RADFORD et al., 2007). In the last decade, FCV-VSD has been reported in the United States and Europe (PEDERSEN et al., 2000; SCHORR-EVANS et al., 2003; HURLEY et al., 2004), although it has not yet been described in Brazil.

\section{Pathogeny and clinical signs}

FCV infection is associated with acute oral and/or respiratory disease, and a transient viremia may occur three to four days after the oronasal infection. Thus, the virus may be detected in other tissues (RADFORD et al., 2009). Transplacental infection was not confirmed, although FCV has been isolated from aborted fetuses (ELLIS, 1981). Although FCV infection is primarily associated with the respiratory tract, viral replication is not restricted this tissue (RADFORD et al., 2007). Strains differ in tropism and pathogenicity, and different clinical manifestations may be observed (GASKELL \& WARDLEY, 1978). Infected cats may have subclinical infections or fever, pharyngitis, chronic gingivitis/ stomatitis and synovitis with increased synovial fluid, which manifests in the form of lameness. The pathogenesis of synovitis is unclear, although tissue deposition of immune complexes may play a key role in the development of this condition (RADFORD et al., 2007, 2009). Death may also occur in infected cats because of pneumonia (LOVE, 1975) and nervous system disease (SATO et al., 2004).

The severity of clinical signs depends on the route of exposure, presence of concurrent infection, age group, viral dose and immune status of the host, including its vaccination history (RADFORD et al., 2009). Some cats remained carriers after acute FCV infection. FCV may be in the tonsillar epithelium, although tonsillectomy does not eliminate the carrier status (RADFORD et al., 2007). The presence of carrier feline is common, ranging from 15 to $91 \%$, and these cats spread the virus throughout the environment (RADFORD et al., 2009). Certain cats shed the virus through the oropharynx for weeks, months or even years, although the mechanisms involved in the establishment of such viral persistence are not well 
known (RADFORD et al., 2007). In addition, there is evidence that FCV has promoted the evolution of the immunodominant regions of the capsid through the selection of mutants that escape neutralization by the host immune response (RADFORD et al., 2007, 2009).

The pathogenesis of the FCV-VSD syndrome is not well known (RADFORD et al., 2009). Factors such as viral evolution and/or immunomediated and environmental components may be related to the development of this syndrome (HURLEY et al., 2004). The clinical manifestations are pyrexia, cutaneous edema, ulcerative lesions in the head and gums, jaundice resulting from hepatic necrosis and pancreatitis, disseminated vasculitis and hemorrhaging (RADFORD et al., 2009).

Immunity

The immune response against FCV infection depends on host factors, viral dose and strain and feline immune status. Maternal antibodies are important for protection during the first few weeks of life, although they may affect vaccination. Data on the magnitude/length of passive immunity against FCV are scarce, although the levels of antibodies against FCV are mostly high and persist for 10 to 14 weeks (RADFORD et al., 2007, 2009).

Neutralizing antibodies are detectable seven days post-infection and are key for active immunity (RADFORD et al., 2007, 2009). The titers of antibodies against FCV have been correlated with protection against viral homologous strains/ isolates (POVEY \& INGERSOLL, 1975). However, the previously developed immunity will only partly protect against heterologous strains (RADFORD et al., 2009). Heterologous protection depends on the virus strain involved; however, a reduction in clinical signs and even of oral viral shedding in some cases may be observed (POVEY \& INGERSOLL, 1975). Cats exposed to the virus may not show disease even in the absence of detectable antibodies, suggesting that other immune mechanisms might be involved. The cellular immune response has been observed in cats vaccinated against FCV (RADFORD et al., 2009).

\section{Diagnosis}

The diagnosis of FCV and FeHV-1 is conducted by isolation in cellular culture (CC), immunofluorescence assay (IFA), serology and polymerase chain reaction (PCR). PCR is used to detect RNA/DNA from conjunctival, nasal or oropharyngeal swabs, blood or biopsies (THIRY et al., 2009). The sensitivity of reverse transcriptionPCR (RT-PCR) depends on the primers and detected strain because of the genetic variability of FCV (RADFORD et al., 2009; THIRY et al., 2009).

Isolation in $\mathrm{CC}$ is less sensitive than PCR, although the viruses replicate readily in Crandell Rees feline kidney (CRFK) lines (CRANDELL et al., 1973). FCV has a rapid replication rate that may complicate the identification of FeHV-1 in concurrent infections (GASKELL et al., 2007; RADFORD et al., 2007). PCR is a good alternative in these cases. Positive viral isolation indicates that viruses are actively replicating, albeit insufficiently in chronic infections in the case of FCV and latent FeHV-1 infections (RADFORD et al., 2009; THIRY et al., 2009). Furthermore, viral inactivation during transport resulting from the presence of antibodies and extracellular fluids may affect in vitro replication (GASKELL et al., 2007).

Antibodies against FCV and FeHV-1 may be detected by serum neutralization (SN) or enzymelinked immunosorbent assays (ELISA) from serum, aqueous humor and cerebrospinal fluid. SN is widely used, although some cats survive a severe infection without developing detectable antibodies (RADFORD et al., 2009; THIRY et al., 2009). The paired serology may aid in diagnosis, although the difficulty in collecting sufficient amounts of blood from cats, time required obtaining results, and low antibody titer in convalescent cats and those latently infected with FeHV-1 are disadvantages of using SN. Furthermore, the presence of antibodies may not be correlated with active infection because the detection of antibodies fails to differentiate between the vaccinated cats and naturally infected cats (MAGGS, 2005).

The interpretation of serology against FCV must be performed carefully. False negatives may be detected when there are neutralizing antibodies that have no cross-reaction with the strain used in the test. Higher titers may be observed with homologous strains than with heterologous strains (RADFORD et al., 2009).

The diagnosis of FCV-VSD syndrome is performed based on clinical signs, epidemiology (morbidity and mortality) and macroscopic and microscopic lesions that result from biopsies; in such cases, immunohistochemistry and IFA have been used to detect viral antigens present in the tissues. In addition, the nucleotide sequencing of VP1 coding region can also be used in the diagnosis of FCV-VSD (RADFORD et al., 2009).

Control, prevention and vaccination

Prevention and control measures, including good hygiene practices and vaccination with three 
applications starting on the ninth week of life, annual boosters after the third application, and revaccination (one dose) in the third year (RADFORD et al., 2009; THIRY et al., 2009) are required to reduce the prevalence/incidence of infection. Environmental disinfection after outbreaks of FCV and FeHV1 infections, especially in breeding catteries or shelters, are recommended to prevent the virus from spreading. FCV may persist in the environment for approximately one month. Effective disinfectants include sodium hypochlorite, potassium monosulfate peroxide, chlorine dioxide and commercial products (RADFORD et al., 2009).

Vaccines against FCV and FeHV-1 have been commercially available since the 1970s (GASKEL et al., 2007; RADFORD et al., 2007). Live and inactivated vaccines for the parenteral administration against FCV and FeHV-1 and (in some countries) live intranasal vaccines against FeHV-1 are marketed (ORR et al., 1980; LAPPIN et al., 2006). However, vaccines do not provide full protection and clinical disease and viral shedding still may occur (LAPPIN et al., 2006); therefore, massive vaccination should be performed, aiming to reduce the incidence of the disease.

Vaccines also fail to prevent cats from being carriers of both viruses. Furthermore, the attenuated vaccine against FeHV-1 may induce latent infection (GASKELL et al., 2007). Vaccine failures entail possible periodic reactivations of latency, allowing transmission of the virus to susceptible cats in the case of FeHV-1 (GASKELL et al., 2007). Conversely, the challenge of vaccination against FCV is related to the genetic diversity among isolates. Although the vaccine strain is considered to be broadly reactive, the vaccines fail to provide adequate protection against all of the field isolates or against the carrier status (RADFORD et al., 2007, 2009). The prevalence of FCV is greater than FeHV-1 because of this incomplete vaccine protection and high FCV infectivity.

The strain that is commonly used worldwide in vaccines the FCV-F9. FCV-255 and FCV-F7 are also used and the strains FCV-G1 and FCV-431 are used in Japan and Europe, respectively (RADFORD et al., 2009). However, current vaccines will not prevent the FCV-VSD syndrome because outbreaks have been reported in vaccinated cats (HURLEY, 2004). An FCV-VSD outbreak after vaccination in New Zealand caused 32\% mortality of cats, and different viral strains were isolated (SCHORR-EVANS et al., 2003) and defined as vaccine breakdown strains [VBS] (RADFORD et al., 2007, 2009). Vaccine failures against FCV and FeHV-1 may also be related to pre-existing carrier status, intercurrent illness and/or interference of passive immunity or sub-protective vaccine titers (GASKELL \& WARDLEY, 1978).

In Brazil, limited data about the vaccination status of cats included in serological and viral isolation studies conducted in RS is available. These studies have shown that approximately $10 \%$ of the populations of domestic cats are vaccinated (JOHANN et al., 2009; HENZEL et al., 2012b; HENZEL et al., 2013).

\section{Treatment}

Many antiviral drugs used in veterinary medicine only inhibit the replication of DNA viruses or retroviruses, and antiviral therapy for FCV infections has not been introduced in the clinical practice (RADFORD et al., 2009). Ribavirin is one of the few antiviral agents capable of inhibiting the in vitro replication of FCV, although it is apparently toxic to cats, and its side effects have prevented its systemic application (POVEY, 1978). Feline interferon (IFN) omega inhibits in vitro replication, although field studies are not available (RADFORD et al., 2009). Cats severely affected by FCV-VSD have been treated with support therapy (fluid and antibiotic therapy), as well as steroids and IFN, and clinical improvement has been reported informally (FOLEY, 2006).

No antiviral has been developed specifically for FeHV-1, although many have been tested for their efficacy against the virus and safety in cats. Broad-spectrum antibiotics that achieve high penetration in the respiratory tract are applied in all cases to inhibit secondary bacterial infections. Nasal discharge may be reduced by using saline solutions and topical ointments. Mucolytic drugs, including bromhexine, may also be useful (GASKELL et al., 2007; FONTENELLE et al., 2008; MALIK et al., 2009).

Certain drugs have been proposed for the treatment of FeHV-1 ocular infections, including bromovinyldeoxyuridine, cidofovir, famciclovir, N-(2-hydroxy propyl) methacrylamide (HPMA), penciclovir, ribavirin, valacyclovir, vidarabine, foscarnet and lactoferrin (MALIK et al., 2009). The efficacy of these drugs is not supported by the published data, although topical application of cidofovir in FeHV-1 primary ocular infection has shown promising results (FONTENELLE et al., 2008). In vitro studies have shown that FeHV-1 is susceptible to feline IFN or recombinant human 
IFN-alpha and the synergistic effect of acyclovir and recombinant human IFN-alpha (GASKELL et al., 2007).

\section{CONCLUSION}

FCV and FeHV-1 are key agents in feline veterinary medicine and have spread globally in this population. The isolation of FeHV-1 and FCV in healthy cats in the southern region of Brazil and great diversity in the genetic sequences of Brazilian isolates of $\mathrm{FCV}$, both among the isolates and in comparison with a known vaccine strain, emphasize the difficulty in in controlling and preventing these viruses. Nevertheless, vaccination is currently the recommended practice for decreasing the clinical cases and viral shedding once treatment methods are ineffective and only provide palliative care. Furthermore, prophylactic measures to avoid contact between domestic animals and feral populations and promote good hygiene practices are relevant for controlling infection and preventing viral spread.

\section{ACKNOWLEDGEMENTS}

R. Weiblen (301339/04-0) is a recipient of Brazilian Council for Research (CNPq) scholarships.

\section{REFERENCES}

CRANDELL, R.A.; MAURER, F.D. Isolation of a feline virus associated with intranuclear inclusion bodies. Proceedings of the Society for Experimental Biology and Medicine, v.97, n.3, p.487-490, 1958.

CRANDELL, R.A. et al. Development and characterization and viral susceptibility of a feline (Felis catus) renal cell line (CRFK). In vitro, v.9, p.76-85, 1973. Accessed: Jan. 20, 2014. doi: $10.1007 / \mathrm{bf0} 2618435$.

DANIELS, M.J. et al. Feline viruses in wildcats from Scotland. Journal of Wildlife Disease, v.35, n.1, p.121-124, 1999. Available from: $<$ http:// www.jwildlifedis.org/doi/pdf/10.7589/00903558-35.1.121>. Accessed: Jan. 20, 2014. doi: 10.7589/0090-3558-35.1.121.

ELLIS, T.M. Jaundice in a Siamese cat with in utero feline calicivirus infection. Australian Veterinary Journal, v.57, n.8, p.383-385, 1981.

FASTIER, L.B. A new feline virus isolated in tissue culture. American Journal of Veterinary Research, v.18, n.67, p.382$389,1957$.

FILONI, C. et al. First evidence of feline herpesvirus, calicivirus, parvovirus, and Ehrlichia exposure in Brazilian freeranging felids. Journal of Wildlife Disease, v.42, n.2, p.470477, 2006. Available from: <http://www.jwildlifedis.org/doi/ pdf/10.7589/0090-3558-42.2.470>. Accessed: Jan. 20, 2014 doi: $10.7589 / 0090-3558-42.2 .470$.
FOLEY J. et al. Virulent systemic feline calicivirus infection: local cytokine modulation and contribution of viral mutants. Journal of Feline Medicine and Surgery, v.8, n.1, p.55-61, 2006. Available from: <http://www.jfm.sagepub.com/content/8/1/55.full.pdf $>$. Accessed: Jul. 21, 2014. doi: 10.1016/j.jfms.2005.08.002.

FONTENELLE, J.P. et al. Effect of topical ophthalmic application of cidofovir on experimentally induced primary ocular feline herpesvirus-1 infection in cats. American Journal of Veterinary Research, v.69, n.2, p.289-293, 2008. Available from: <http:// avmajournals.avma.org/doi/abs/10.2460/ajvr.69.2.289>. Accessed: Jul. 21, 2014. doi: 10.2460/ajvr.69.2.289.

GASKELL, R. et al. Feline herpesvirus. Veterinary Research, v.38, n.2, p.337-354, 2007. Avaiable from: <http://www.vetres. org/articles/vetres/pdf/2007/02/v07073.pdf>. Accessed: Jan. 20, 2014. doi: $10.1051 /$ vetres:2006063.

GASKELL, R.; KNOWLES, J. Feline respiratory disease. In Practice: Journal of British Veterinary Association, v.11, n.1, p. 23-26, 1989.

GASKELL, R.M.; POVEY, R.C. Feline viral rhinotracheitis: sites of virus replication and persistence in acutely and persistently infected cats. Research in Veterinary Science, v.27, n.2, p.167$174,1979$.

HENZEL, A. et al. Genetic and phylogenetic analyses of capsid protein gene in feline calicivirus isolates from Rio Grande do Sul in southern Brazil. Virus Research, v.163, n.2, p.667-671, 2012a. Available from: $<$ http://www.sciencedirect.com/science/article/pii/ S0168170211004965>. Accessed: Jan. 22, 2014. doi: 10.1016/j. virusres.2011.12.008.

HENZEL, A. et al. Isolation and identification of feline calicivirus and feline herpesvirus in Southern Brazil. Brazilian Journal of Microbiology, v.432, n.2, p.560-568, 2012b. Available from: $<$ http://www.scielo.br/pdf/bjm/v43n2/17.pdf $>$. Accessed: Jan. 20, 2014. doi: 10.1590/S1517-83822012000200017.

HENZEL, A. et al. Serological Survey of Feline Calicivirus and Felid herpesvirus in Rio Grande do Sul, Brazil. Acta Scientiae Veterinariae, v.41, p.1-6, 2013. Available from: <http://www. ufrgs.br/actavet/41/pub1153.pdf>. Accesed: Jan. 21, 2014.

HURLEY, K.E. et al. An outbreak of virulent systemic feline calicivirus disease. Journal of the American Veterinary Medical Association, v.224, n.2, p.241-249, 2004. Available from: <http:// avmajournals.avma.org/doi/abs/10.2460/javma.2004.224.241>. Accessed: Jul. 21, 2014. doi: 10.2460/javma.2004.224.241.

JOHANN, J.M. et al. Serum survey for antibodies to coronavirus, herpesvirus, calicivirus, and parvovirus in domestics cats from Rio Grande do Sul, Brazil. Arquivo Brasileiro de Medicina Veterinária e Zootecnia, v.61, n.3, p.752-754, 2009. Available from: <http://www.scielo.br/pdf/abmvz/ v61n3/33.pdf $>$. Accessed: Jan. 21, 2014. doi: 10.1590/S010209352009000300033

LAPPIN, M.R. et al. Effects of a single dose of an intranasal feline herpesvirus 1 , calicivirus, and panleukopenia vaccine on clinical signs and virus shedding after challenge with virulent feline herpesvirus 1. Journal of Feline Medicine and Surgery, v.8, n.3, p.158-163, 2006. Available from: <http://jfm.sagepub.com/ content/8/3/158.long $>$. Accessed: Jan. 22, 2014. doi: 10.1016/j. jfms.2005.12.001 
LOVE, D.N. Pathogenicity of a strain of feline calicivirus for domestic kittens. Australian Veterinary Journal, v.51, n.12, p.541-546, 1975.

MAEDA, K. et al. Properties and functions of feline herpesvirus type 1 glycoproteins. Journal of Veterinary Medical Science, v.60, n.8, p.881-888, 1998. Available from: $<$ https://www.jstage. jst.go.jp/article/jvms/60/8/60_8_881/_pdf $>$. Accessed: Jan. 21, 2014. doi: $10.1292 /$ jvms. 60.881 .

MAGGS, D.J. Update on pathogenesis, diagnosis, and treatment of feline herpesvirus type 1. Clinical Techniques in Small Animal Practice, v.20, n.2, p.94-101, 2005. Available from: <http:// www.sciencedirect.com/science/article/pii/S1096286704001094>. Accessed: Jan. 20, 2014. doi: 10.1053/j.ctsap.2004.12.013.

MALIK, R. et al. Treatment of feline herpesvirus-1 associated disease in cats with famciclovir and related drugs. Journal of Feline Medicine and Surgery, v.11, n.1, p.40-48, 2009. Avaiable from: $<$ http://www.jfm.sagepub.com/content/11/1/40.full.pdf $>$. Accessed: Jul. 21, 2014. doi: 10.1016/j.jfms.2008.11.012.

MENCKE, N. et al. Transmission of feline calicivirus via the cat flea (Ctenocephalides felis). Parasitology Research, v.105, n.1, p.185-189, 2009. Available from: $<$ http://link.springer.com/article /10.1007\%2Fs00436-009-1381-5>. Accessed: Jan. 22, 2014. doi 10.1007/s00436-009-1381-5.

NASISSE, M.P. et al. Isolation of feline herpesvirus 1 from the trigeminal ganglia of acutely and chronically infected cats. Journal of Veterinary Internal Medicine, v.6, n.2, p.102103, 1992.

ORR, C.M. et al. Interaction of an intranasal combined feline viral rhinotracheitis, feline calicivirus vaccine and the FVR carrier state. Veterinary Record, v.106, n.8, p.164-166, 1980.

PEDERSEN, N.C. et al. An isolated epizootic of hemorrhagic-like fever in cats caused by a novel and highly virulent strain of feline calicivirus. Veterinary Microbiology, v.73, n.4, p.281-300, 2000. Available from: $<\mathrm{http}: / / \mathrm{www}$. sciencedirect.com/science/article/pii/ S0378113500001838>. Accessed: Jan. 22, 2014. doi: 10.1016/ S0378-1135(00)00183-8.

POVEY, R.C. Effect of orally administered ribavirin on experimental feline calicivirus infection in cats. American Journal of Veterinary Research, v.39, n.8, p.1337-1341, 1978.

POVEY, R.C. A review of feline viral rhinotracheitis (feline herpesvirus I infection). Comparative Immunology Microbiology and Infectious Diseases, v.2, n.2-3, p.373-387, 1979. Avaiable from: <http://www.sciencedirect.com/science/ article/pii/0147957179900237>. Accessed: Jan. 22, 2014. doi: 10.1016/0147-9571(79)90023-7.

POVEY, C.; INGERSOLL, J. Cross-protection among feline calicviruses. Infectious Immunology, v.11, n.5, p.877-885, 1975. Available from: <http://www.ncbi.nlm.nih.gov/pmc/articles/ PMC415151/pdf/iai00233-0001.pdf>. Accessed: Jan. 22, 2014.

RADFORD, A.D. et al. Endemic infection of a cat colony with a feline calicivirus closely related to an isolate used in live attenuated vaccines. Vaccine, v.19, n.31, p.4358-4362, 2001 Available from: $<$ http://www.sciencedirect.com/science/article/pii/ S0264410X01001918>. Accessed: Jan. 22, 2014. doi: 10.1016 S0264-410X(01)00191-8.

RADFORD, A.D. et al. Feline calicivirus. Veterinary Research, v.38, n.2, p.319-335, 2007. Available from: <http://www.vetres. org/articles/vetres/abs/2007/02/v06220/v06220.html>. Accessed: Jan. 22, 2014. doi: 10.1051/vetres:2006056

RADFORD, A.D. et al. Feline calicivirus infection ABCD guidelines on prevention and management. Journal of Feline Medicine and Surgery, v.11, n.7, p.556-564, 2009. Available from: $<$ http://jfm.sagepub.com/content/11/7/556.long $>$. Accessed: Jan. 22, 2014. doi: 10.1016/j.jfms.2009.05.004.

RUTHNER-BATISTA, H.B. et al. Neutralizing antibodies against feline herpesvirus type 1 in captive wild felids of Brazil. Journal of Zoo Wildlife Medicine, v.36, p.447-450, 2005. Available from: $<$ http://www.ufrgs.br/labvir/artigos/artigo39.pdf $>$. Accessed: Jan. $22,2014$.

SATO, Y. et al. Properties of a calicivirus isolated from cats dying in an agitated state. Veterinary Record, v.155, n.25, p.800805, 2004. Available from: <http://veterinaryrecord.bmj.com/ content/155/25/800.long >. Accessed: Jan. 22, 2014.

SCHORR-EVANS, E.M. et al. An epizootic of highly virulent feline calicivirus disease in a hospital setting in New England. Journal of Feline Medicine and Surgery, v.5, n.4, p.217-226, 2003. Available from: $<\mathrm{http}: / / \mathrm{jfm}$.sagepub.com/content $/ 5 / 4 / 217$. long.>. Accessed: Jan. 22, 2014. doi: 10.1016/S1098-612X(03) 00008-1.

THIRY, E. et al. Feline herpesvirus infection ABCD guidelines on prevention and management. Journal of Feline Medicine and Surgery, v.11, n.7, p.547-555, 2009. Available from: $<$ http://jfm. sagepub.com/content/11/7/547.long $>$. Accessed: Jan. 22, 2014. doi: 10.1016/j.jfms.2009.05.003.

WEIBLEN, R. et al. Isolation of feline calicivirus from cats in Brazil. Veterinary Record, v.122, n.4, p.94-95, 1988 